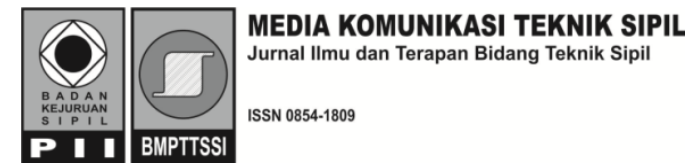

\title{
Studi Karakteristik Campuran Aspal Beton Lapis Aus (AC-WC) Menggunakan Aspal Penetrasi 60/70 dengan Penambahan Lateks
}

\author{
I Nyoman Arya Thanaya \\ Jurusan Teknik Sipil, Fakultas Teknik Universitas Udayana, Denpasar \\ Kampus Bukit Jimbaran, Kuta Selatan, Jimbaran, Badung, Kabupaten Badung, Bali \\ E-mail: aryathanaya@ymail.com \\ I Gusti Raka Puranto \\ Jurusan Teknik Sipil, Fakultas Teknik Universitas Udayana, Denpasar \\ Kampus Bukit Jimbaran, Kuta Selatan, Jimbaran, Badung, Kabupaten Badung, Bali \\ E-mail: rakapurbanto@gmail.com

\section{Nyoman Sapta Nugraha} \\ Jurusan Teknik Sipil, Fakultas Teknik Universitas Udayana, Denpasar \\ Kampus Bukit Jimbaran, Kuta Selatan, Jimbaran, Badung, Kabupaten Badung, Bali \\ E-mail: saptanyoman@gmail.com
}

\begin{abstract}
Asphalt on pavement in long term may undergo hardening, so it needs addition of additive that can make it remain flexible. This experiment tried to produce asphalt concrete wearing course (AC-WC) using asphalt penetration 60/70 with the addition of latex, with aim to know the characteristic of AC-WC mix at the optimum of asphalt content with addition of latex in variation of $0 \%, 2 \%, 4 \%, 6 \%, 8 \%$, and $10 \%$ of the total binder. Latex was initially mixed with the asphalt, then the aggregates were proportioned based on ideal grading. The samples were produced in hotmix process. The density of latex was found 0.977 with dry rubber content of $61.95 \%$. The optimum of asphalt content that was $5.7 \%$, where all Marshall characteristics were met. It was chosen the mix with $4 \%$ latex by total binder where all properties of asphalt binder were still met. It was obtained that the Stability value was $1439.26 \mathrm{~kg}$ ( $\geq 800 \mathrm{~kg})$, Flow $3.84 \mathrm{~mm}(2-4 \mathrm{~mm})$, Marshall Quotient $379.66 \mathrm{~kg} / \mathrm{mm}(\geq 250 \mathrm{~kg} / \mathrm{mm}$ ), VIM 4.437\% (3-5\%), VMA $15.280 \%$ ( $\geq 15 \%$ ), VFB 70.961 ( $\geq$ $65 \%)$. The mixture that contains latex had better resistance to deformation under dynamic creep loading at $40{ }^{\circ} \mathrm{C}$.
\end{abstract}

Keywords: Latex, $A C$-WC, Characteristics.

\begin{abstract}
Abstrak
Aspal pada perkerasan dalam jangka panjang bisa mengalami pengerasan, maka perlu penambahan aditif supaya tetap lentur. Pada penelitian ini dicoba membuat campuran aspal beton lapis aus (AC-WC) menggunakan aspal penetrasi 60/70 dengan penambahan lateks, dengan tujuan untuk mengetahui karakteristik campuan AC-WC pada kadar aspal optimum dengan penambahan variasi lateks 0\%, 2\%, 4\%, 6\%, 8\%, dan 10\% terhadap total perekat. Lateks dicampur terlebih dahulu dengan aspal, kemudian agregat diproporsikan berdasarkan gradasi ideal campuran. Sampel dibuat dengan cara campuran panas. Sampel diuji Marshall dan dynamic creep. Diperoleh berat jenis lateks sebesar 0,977 dan kadar kering karet sebesar 61,95\%. Kadar aspal optimum campuran didapat 5,7\% dimana semua karakeristik Marshall dipenuhi. Dipilih campuran AC-WC dengan variasi lateks $4 \%$ terhadap total perekat dimana semua ketentuan sifat perekat aspal masih dipenuhi. Diperoleh Stabilitas $=1439,26 \mathrm{~kg}(\geq 800 \mathrm{~kg})$, Flow = 3,84 $\mathrm{mm}(2-4 \mathrm{~mm})$, Marshall Quotient $=379,66 \mathrm{~kg} / \mathrm{mm}(\geq 250 \mathrm{~kg} / \mathrm{mm}), V I M=4,437 \%(3-5 \%), V M A=15,280 \%(\geq 15 \%)$, $V F B=70,961$ ( $\geq 65 \%)$. Campuran yang mengandung lateks memiliki kemampuan menahan deformasi lebih baik diuji dengan dynamic creep pada suhu $40{ }^{\circ} \mathrm{C}$.
\end{abstract}

Kata-kata Kunci: Lateks, AC-WC, Karakteristik. 


\section{Pendahuluan}

Saat ini bahan pengikat untuk perkerasan jalan yang banyak digunakan adalah aspal minyak AC 60/70. Untuk meningkatkan kinerja campuran aspal untuk perkerasan yang dalam jangka panjang mengalami deformasi maka perlu penambahan aditif. Pada penelitian dicoba campuran aspal beton lapis aus (AC-WC) menggunakan aspal penetrasi 60/70 dengan penambahan lateks (karet alam cair).

Lateks (karet alam cair) merupakan sumber daya alam yang banyak dihasilkan di Indonesia, karena Indonesia sebagai salah satu penghasil karet terbesar di dunia, sehingga didapat baik dalam jumlah dan kualitas yang dibutuhkan. Pada dasarnya lateks akan menggumpal secara alami dalam waktu beberapa jam. Penggumpalan ini dapat disebabkan oleh timbulnya asam-asam akibat terurainya bahan bukan karet yang terdapat dalam lateks akibat aktivitas mikroorganisme. Maka dari itu, lateks tersebut setelah di sadap diolah terlebih dahulu di pabrik (Ridha, 2011; Aryadi, 2012). Penelitian perihal lateks sudah dilakukan oleh Purbaya (2011) dan Amiruddin (2012). Amiruddin (2012) memakai kadar lateks $0 \%, 2 \%, 4 \%, 6 \%$, $8 \%$, dan $10 \%$ terhadap total perekat sebagai bahan penambah pada aspal untuk campuran HRS-WC dimana aspal yang digunakan adalah aspal AC 60/70 yang disesuaikan dengan kondisi iklim di Indonesia dan banyak digunakan dalam perkerasan jalan. Diperoleh stabilitas yang meningkat dengan bertambahnya kadar lateks.

Jenis agregat yang digunakan pada penelitian ini adalah agregat lokal yang berasal dari PT. Adi Murti di Dusun Badeg Desa Sebudi Kecamatan Selat Kabupaten Karangasem-Bali. Sejauh ini agregat tersebut sudah cukup banyak digunakan sebagai material perkerasan jalan. Dari penelitian sebelumnya oleh Pradnya (2015) didapat nilai keausan sebesar 33,04\%, ini menunjukkan agregat cukup kuat dan tahan untuk tidak mengalami keausan atau kehancuran selama proses pencampuran, penghamparan dan pemadatan.

Adapun tujuan penelitian ini adalah untuk mengetahui karakteristik campuran aspal beton lapis aus (AC-WC) pada kadar aspal optimum (KAO) dengan penambahan lateks.

\section{Material dan Metode}

\section{Material}

Penelitian ini menggunakan alat-alat yang tersedia di Laboratorium Jalan Jurusan Teknik Sipil Fakultas Teknik, Universitas Udayana. Sedangkan bahan yang digunakan terdiri dari agregat alam yang merupakan agregat kasar, agregat halus, dan filler yang diperoleh dari Dusun Badeg Desa Sebudi Kecamatan Selat Kabupaten KarangasemBali. Aspal penetrasi 60/70 yang diperoleh dari UPT Balai Peralatan dan Pengujian Dinas PU Provinsi Bali. Lateks diperolah dari suplier dari Bogor.

\section{Metode}

Pada penelitian ini agregat yang digunakan terdiri dari agregat kasar tertahan saringan nomor 4,75 $\mathrm{mm}$, agregat halus lolos saringan no. $4,75 \mathrm{~mm}$ tertahan saringan nomor $0,075 \mathrm{~mm}$ dan filler lolos saringan nomor $0,075 \mathrm{~mm}$. Ketiga fraksi agregat tersebut diproporsikan sesuai dengan spesifikasi campuran agregat aspal beton (AC-WC). Agregat diproporsikan berdasarkan titik tengah spesifikasi agregat campuran pada Tabel 1. Pengujian material dilakukan sesuai SNI (BSN, 2008a, b; BSN, 2011). Pembuatan dan pengujin campuran dilakukan sesuai standar (DPU, 2003; DPU, 2010)

Tabel 1. Proporsi agregat campuran AC-WC

\begin{tabular}{crrrr}
\hline \multirow{2}{*}{$\begin{array}{c}\text { Ukuran } \\
\text { saringan } \\
(\mathbf{m m})\end{array}$} & $\begin{array}{c}\text { \% berat agregat yang lolos } \\
\text { atas }\end{array}$ & $\begin{array}{c}\text { Batas } \\
\text { bawah }\end{array}$ & $\begin{array}{c}\text { Batas tengah } \\
\text { (gradasi } \\
\text { pilihan) }\end{array}$ & $\begin{array}{c}\text { \% } \\
\text { tertahan }\end{array}$ \\
\hline 25,400 & 100 & 100 & 100 & - \\
19,000 & 100 & 100 & 100 & - \\
12,500 & 100 & 90 & 95 & 5 \\
9,500 & 90 & 77 & 83 & 12 \\
4,750 & 69 & 53 & 61 & 22 \\
2,360 & 53 & 33 & 43 & 18 \\
1,180 & 40 & 21 & 30 & 13 \\
0,600 & 30 & 14 & 22 & 8 \\
0,300 & 22 & 9 & 15 & 7 \\
0,150 & 15 & 6 & 10 & 5 \\
0,075 & 9 & 4 & 6 & 4 \\
\hline Pan & & & & 6 \\
\hline & & & Jumlah & $\mathbf{1 0 0}$ \\
\hline
\end{tabular}

Proporsi agregat sesuai gradasi pilihan tersebut adalah agregat kasar sebanyak 39\%, agregat halus sebanyak $55 \%$ dan filler sebanyak $6 \%$. Kadar aspal divariasi sebesar $4,5 \%$; $5 \%$; 5,5\%; 6\%; dan $6,5 \%$. Dibuat 3 sampel pada masing-masing kadar aspal, kemudian karakteristik campuran diambil dari nilai rata-rata 3 sampel. Pemadatan dilakukan 2x75 tumbukan Marshall dengan berat alat tumbuk 4,5 kg dan tinggi jatuh 45,7 cm (18”). Sampel diuji untuk memperoleh karakteristik Marshall.

\section{Campuran AC-WC dengan kepadatan mutlak}

Derajat Kepadatan Mutlak (Percentage Refusal Density, PRD) adalah rasio antara kepadatan benda 
uji lapangan terhadap kepadatan refusal dalam satuan persen. Dalam implementasinya, nilai PRD dituangkan dalam nilai porositas (VIM) sesuai spesifikasi. Perencanaan campuran beraspal dengan PRD dilakukan sebagai simulasi adanya pemadatan lanjutan oleh lalu-lintas. Dalam pembuatan benda uji PRD, kadar aspal yang dipergunakan adalah kadar aspal yang memberikan nilai VIM Marshall $6 \%$ dan $0,5 \%$ di atas dan di bawah dari kadar aspal tersebut. Pemadatan sampel dilakukan 2x400 dengan diameter cetakan 4 inci.

\section{Penentuan kadar aspal optimum}

Hal ini dilakukan dengan menggunakan metode bar-chart, dimana dibuat bar chart yang menunjukkan rentang kadar aspal yang memenuhi setiap karakteristik Marshall sesuai spesifikasi. Kadar aspal optimum ditentukan pada kadar aspal yang memenuhi semua spesifikasi karakteristik Marshall.

\section{Pengujian stabilitas marshall sisa}

Untuk mengevaluasi keawetan campuran adalah pengujian Marshall perendaman di dalam air pada suhu $60^{\circ} \mathrm{C}$ selama 24 jam. Perbandingan stabilitas yang direndam dengan stabilitas standar, dinyatakan sebagai persen dan disebut Indeks Stabilitas Sisa (IRS), dan dihitung sebagai berikut (DPU, 2003):

$I R S=\frac{\mathrm{MSI}}{\mathrm{MSS}} \times 100$

dimana:

IRS = indeks of retained strength

MSI = stabilitas Marshall kondisi setelah direndam selama 24 jam dengan suhu $60^{\circ} \mathrm{C}$

MSS = stabilitas Marshall kondisi standar (direndam selama 30-40 menit pada suhu $\left.60^{\circ} \mathrm{C}\right)$

Sumber: DPU, 2003; Sukirman, 2003.

\section{Pembuatan benda uji dengan variasi kadar} lateks pada kadar aspal optimum

Aspal dipanaskan sampai cukup leleh, kemudian di tuangkan sebanyak yang diperlukan untuk kadar aspal optimum (5,7\% atau 62,7 gram) ke dalam wadah pencampur, kemudian lateks dituangkan sebanyak yang dibutuhkan kedalam wadah yang sama kemudian di aduk rata. Kemudian agregat yang telah dipanaskan 150-155 ${ }^{\circ} \mathrm{C}$ sebanyak 1100 gram dimasukkan ke dalam wadah pencampur, terus diaduk sampai agregat terselimuti aspal yang sudah dicampur lateks secara merata. Masukkan campuran ke dalam mould dirojok dengan batang besi dia $12 \mathrm{~mm}$ dibagian sisi berkeliling 15 kali dan dibagian tengah 10 kali, lalu ditumbuk 2x75 kali. Selanjutnya dilakukan pengukuran kepadatan sampel, perhitungan volumetrik: void in mineral aggregate (VMA), void in mix (VIM), void filled with bitumen (VFB) kemudian dilakukan tes stabilitas dan flow.

\section{Pengujian kadar lateks kering}

Pengujian ini dilakukan dengan menimbang seberat tertentu lateks cair, kemudian dipanaskan secara perlahan sampai beratnya konstan. Kadar lateks kering adalah berat kering dibagi berat semula lateks cair.

\section{Pengujian dynamic creep}

Uji dynamic creep dilakukan dengan memakai alat Universal Testing Machine (UTM) dengan dengan seting parameter: loading function: haversine; cyclic loading stress $100 \mathrm{kPa}$; seating stress $5 \mathrm{kPa}$; cycle duration: 1000 millisecond (ms); cycle repetition time: $1000 \mathrm{~ms}$; preload stress $20 \mathrm{kPa}$; preload time: $600 \mathrm{~s}$; termination cycle count: 3600 ; temperature: $40^{\circ} \mathrm{C}(\mathrm{BS}, 2005)$. Hasil uji dianalisa dan digrafikkan antara beban berulang dan regangan (strain), dan kekakuan rangkak (creep stiffness) yang dihitung dengan Persamaan 2.

Creep stiffness $=\frac{\text { stress }}{\text { strain }}$

Kemiringan (slope) dari dynamic creep curve, diambil dari bagian yang lurus/linier pada grafik hubungan beban berulang dan regangan, dimana dicari linear trend line dengan bentuk seperti pada Persamaan 3.

$y=a x+b$

Kemudian koefisien variable $\mathrm{x}$, yaitu koefisien a (nilai kemiringan), dianalisa sesuai Tabel 2.

Tabel 2. Tipikal nilai kemiringan tes creep dinamik (creep slope), (Alderson, 1995).

\begin{tabular}{cccc}
\hline $\begin{array}{c}\text { Temperatur } \\
\text { tahunan rata2 } \\
\text { perkerasan }\left({ }^{\mathbf{0}} \mathbf{C}\right)\end{array}$ & $\begin{array}{c}\text { Beban lalu lintas } \\
\text { berat } \\
>\mathbf{1 0}^{\mathbf{6}} \mathbf{E S A}\end{array}$ & $\begin{array}{c}\text { Beban lalu lintas } \\
\text { sedang }\end{array}$ & $\begin{array}{c}\text { Beban lalu lintas } \\
\text { ringan }\end{array}$ \\
\hline 30 & $<0,5$ & $0, \mathbf{1 0}^{\mathbf{5}}$ to $\mathbf{1 0}^{\mathbf{6}} \mathbf{E S A}$ & $<\mathbf{5 \times 1 0}^{\mathbf{5}} \mathbf{E S A}$ \\
$20-30$ & $<1$ & $0,5-3$ & $>3-6$ \\
$10-20$ & $<2$ & $1,0-6$ & $>6-10$ \\
\hline
\end{tabular}




\section{Hasil dan Pembahasan}

\section{Pengujian agregat}

Pengujian agregat yang dilakukan meliputi: pengujian agregat kasar, agregat halus dan filler. Pengujian agregat kasar meliputi: analisa saringan, berat jenis dan penyerapan, angularitas, kadar lumpur atau lempung, kelekatan agregat terhadap aspal, keausan agregat (abrasi) dan keawetan agregat (soundness test) dan hasilnya seperti pada Tabel 3.

Pengujian agregat halus meliputi: analisis saringan, berat jenis dan penyerapan, angularitas dan kebersihan agregat halus dengan cara setara pasir (sand equivalent), hasilnya disajikan pada Tabel 4. Berat jenis filler, diperoleh sebesar 2,407.

\section{Pengujian Aspal Penetrasi 60/70}

Aspal yang digunakan adalah aspal keras/padat dengan penetrasi 60/70. Adapun pemeriksaan yang dilakukan di laboratorium adalah pengujian penetrasi, titik nyala, titik lembek, daktilitas, berat jenis aspal dan pemeriksaan kehilangan berat aspal. Hasil pengujian aspal diberikan pada Tabel 5.

\section{Hasil pengujian lateks}

Pengujian lateks yang dilakukan meliputi berat jenis lateks dan kadar karet kering (DSNI, 2002). Hasil pengujian dapat dilihat pada Tabel 6.

\section{Karakteristik Campuran AC-WC}

Dari pengujian Marshall (didapatkan dua data, yaitu nilai stabilitas dan flow. Untuk mendapatkan nilai stabilitas yang tepat, maka dari pembacaan dial perlu dikalibrasi terdulu untuk mendapatkan nilai dengan satuan gaya $\mathrm{kN}$ dan dikonversikan ke satuan Kg, kemudian nilai kalibrasi tersebut dikali dengan hasil angka koreksi yang didapat berdasarkan tinggi benda uji. Hasil dari nilai stabilitas yang dibagi dengan nilai flow disebut Marshall Quotient. Dari Tabel 7 terlihat nilai karakteristik dari kadar aspal yang sudah memenuhi spesifikasi. VIM kepadatan membal (percentage of refusal density-PRD) disajikan pada Tabel 8.

Hasil uji Marshall, dianalisa dan digambarkan dengan bar chart pada Gambar 1, untuk memperoleh kadar aspal optimum (KAO).

Tabel 3. Hasil pengujian agregat kasar

\begin{tabular}{|c|c|c|c|c|c|}
\hline Jenis Pengujian & & & & & \multirow{3}{*}{ Spesifikasi } \\
\hline \multirow{2}{*}{ Berat Jenis \& Penyerapan } & Bulk & SSD & Apparent & Penyerapan & \\
\hline & 2,304 & 2,333 & 2,372 & $1,242 \%$ & \\
\hline Angularitas & \multicolumn{4}{|c|}{$99,985 \%$} & $\geq 95 \%$ \\
\hline Kadar lumpur & \multicolumn{4}{|c|}{$0,670 \%$} & $\leq 1 \%$ \\
\hline Soundness test & \multicolumn{4}{|c|}{$5,128 \%$} & $\leq 18 \%$ \\
\hline Keausan agregat & \multicolumn{4}{|c|}{$32,040 \%$} & Maks $40 \%$ \\
\hline Kelekatan agregat terhadap aspal & \multicolumn{4}{|c|}{$97,500 \%$} & Min $95 \%$ \\
\hline
\end{tabular}

Tabel 4. Hasil pengujian agregat halus

\begin{tabular}{|c|c|c|c|c|c|}
\hline \multirow{3}{*}{$\begin{array}{r}\text { Jenis Pengujian } \\
\text { Berat Jenis \& penyerapan }\end{array}$} & \multicolumn{4}{|c|}{ Hasil } & \multirow{2}{*}{ Spesifikasi } \\
\hline & Bulk & SSD & Apparent & Penyerapan & \\
\hline & 2,206 & 2,221 & 2,240 & $0,675 \%$ & \\
\hline Angularitas & \multicolumn{4}{|c|}{$46,117 \%$} & $\operatorname{Min} 45 \%$ \\
\hline Sand equivalent & \multicolumn{4}{|c|}{$78,560 \%$} & $\geq 60 \%$ \\
\hline
\end{tabular}

Tabel 5. Hasil pengujian aspal penetrasi $60 / 70$

\begin{tabular}{lcc}
\hline \multicolumn{1}{c}{ Pengujian } & Hasil & Spesifikasi \\
\hline Penetrasi & 66,71 & $60-70$ \\
Titik nyala & $347^{\circ} \mathrm{C}$ & $\geq 232^{\circ} \mathrm{C}$ \\
Titik lembek & $49,75^{\circ} \mathrm{C}$ & $\geq 48^{\circ} \mathrm{C}$ \\
Berat jenis & 1,023 & $\geq 1,0$ \\
Daktilitas & $136 \mathrm{~cm}$ & Min. $100 \mathrm{~cm}$ \\
Kehilangan berat aspal & $0,310 \%$ & Maks. $0,8 \%$ \\
\hline
\end{tabular}

Tabel 6. Hasil pengujian lateks

\begin{tabular}{clcc}
\hline Material & \multicolumn{1}{c}{ Jenis pengujian } & Hasil & Spesifikasi \\
\hline \multirow{2}{*}{ Lateks } & Berat jenis & 0,977 & - \\
& Kadar karet kering & 61,950 & Min. 60 \\
\hline
\end{tabular}


Tabel 7. Karakteristik campuran AC-WC pada vasiasi kadar aspal

\begin{tabular}{lrrrrrc}
\hline \multirow{2}{*}{ Karakteristik campuran } & \multicolumn{7}{c}{ Kadar aspal (\%) } & \multirow{2}{*}{ Persyaratan } \\
\cline { 2 - 6 } & \multicolumn{1}{c}{5,5} & \multicolumn{1}{c}{5,5} & \multicolumn{1}{c}{6} & \multicolumn{1}{c}{6,5} & \\
\hline Stabilitas $(\mathrm{kg})$ & 1193,230 & 1269,850 & 1314,220 & 1264,390 & 1206,560 & Min. 800 \\
Flow $(\mathrm{mm})$ & 3,270 & 3,350 & 3,510 & 3,680 & 3,920 & $2-4$ \\
Marshall Quotient $(\mathrm{kg} / \mathrm{mm})$ & 363,610 & 384,390 & 375,800 & 344,250 & 309,470 & Min. 250 \\
VIM Marshall $(\%)$ & 8,004 & 6,667 & 5,274 & 4,345 & 3,773 & $3-5$ \\
VMA (\%) & 15,909 & 15,624 & 15,304 & 15,412 & 15,839 & Min. 15 \\
VFB $(\%)$ & 49,745 & 57,328 & 65,541 & 71,818 & 76,185 & Min. 65 \\
\hline
\end{tabular}

Tabel 8. VIM kepadatan membal (PRD)

\begin{tabular}{|c|c|c|c|c|}
\hline \multirow{2}{*}{$\begin{array}{c}\text { Karakteristik } \\
\text { campuran }\end{array}$} & \multicolumn{3}{|c|}{ Kadar aspal (\%) } & \multirow[b]{2}{*}{ Persyaratan } \\
\hline & 4,75 & $\begin{array}{c}5,25 \\
(\mathrm{pd} \text { VIM 6\%) }\end{array}$ & 5,75 & \\
\hline VIM PRD (\%) & 4,767 & 4,082 & 3,270 & VIM Marshall-VIM PRD < 3\% \\
\hline
\end{tabular}

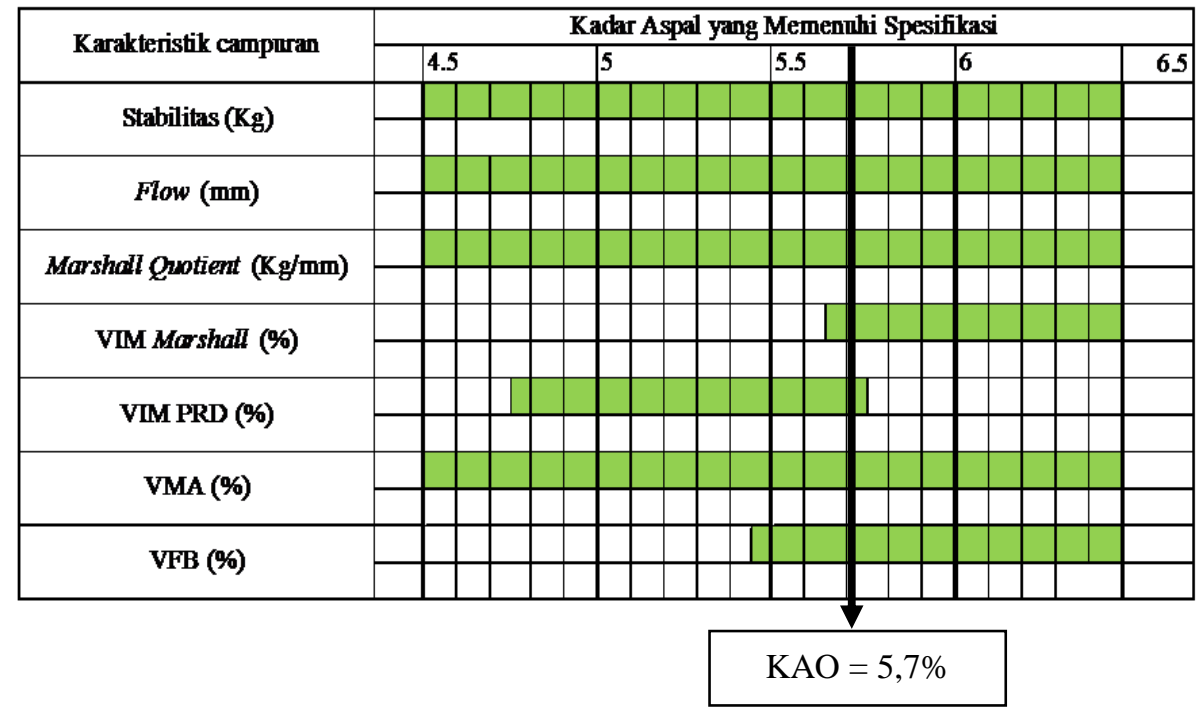

Gambar 1. Penentuan kadar aspal optimum

\section{Karakteristik campuran AC-WC pada kadar aspal optimum}

Setelah mengetahui kadar aspal optimum (KAO), maka dibuatkan kembali sampel pada KAO dan dicari nilai karakteristiknya seperti pada Tabel 9.

\section{Karakteristik campuran AC-WC dengan penambahan lateks}

Karakteristik campuran pada kadar aspal optimum dengan variasi lateks, disajikan pada Tabel 10, dan Gambar 2 sd 7.

Gambar 2 menunjukkan nilai stabilitas meningkat dengan bertambahnya kadar lateks. Hal ini terjadi karena aspal dengan penambahan lateks menyebabkan aspal berubah menjadi lebih keras kemudian pada kadar lateks $10 \%$ menurun karena campuran tersebut mulai getas. Pada Gambar 3 nilai flow meningkat sesuai dengan bertambahnya kadar lateks. Flow yang diperoleh merupakan indikator terhadap lentur sehingga semakin besar nilai flow mengindikasikan bahwa campuran beraspal semakin lentur. Gambar 4 menyajikan nilai Marshall Quotient meningkat tetapi pada kadar lateks $10 \%$ terjadi penurunan. Semakin besar nilai Marshall Quotient yang dihasilkan berarti campuran semakin kaku.

Gambar 5 memperlihatkan bahwa nilai VIM menurun, hal ini disebabkan dengan bertambahnya total perekat ke dalam campuran AC-WC menyebabkan rongga udara dalam campuran semakin kecil. Gambar 5 menunjukkan nilai VMA menurun sesuai dengan bertambahnya kadar lateks, hal ini menunjukan bahwa rongga antara agregat dalam campuran semakin kecil sehingga campuran semakin rapat. Gambar 6 mengilustrasikan nilai VFB semakin meningkat sesuai dengan bertambahnya kadar lateks, hal ini berarti semakin meningkatnya rongga terisi perekat aspal dan lateks. 
I Nyoman Arya Thanaya, I Gusti Raka Puranto, I Nyoman Sapta Nugraha

Studi Karakteristik Campuran Aspal Beton Lapis Aus (AC-WC) Menggunakan Aspal Penetrasi 60/70 dengan Penambahan Lateks

Tabel 9. Karakteristik campuran AC-WC pada kadar aspal optimum

\begin{tabular}{lcc}
\hline \multicolumn{1}{c}{ Karakteristik campuran } & Kadar aspal optimum 5,7\% & Persyaratan campuran \\
\hline Stabilitas (kg) & 1276,70 & Min. 800 \\
Flow $(\mathrm{mm})$ & 3,76 & $2-4$ \\
Marshall Quotient $(\mathrm{kg} / \mathrm{mm})$ & 340,27 & Min 250 \\
VIM Marshall $(\%)$ & $4.682,00$ & $3-5$ \\
VMA (\%) & 15,150 & Min. 15 \\
VFB (\%) & 69,098 & Min 65 \\
Stabilitas sisa $(\%)$ & 93,90 & Min 90 \\
\hline
\end{tabular}

Tabel 10. Campuran AC-WC dengan panambahan lateks

\begin{tabular}{|c|c|c|c|c|c|c|c|}
\hline \multirow{2}{*}{$\begin{array}{c}\text { Karakteristik } \\
\text { Campuran }\end{array}$} & \multicolumn{6}{|c|}{ Kadar lateks pada kadar aspal optimum (\%) } & \multirow{2}{*}{ Spek. } \\
\hline & $\mathbf{0}$ & 2 & 4 & 6 & 8 & 10 & \\
\hline Stabilitas $(\mathrm{Kg})$ & 1276,700 & 1380,420 & 1439,260 & 1572,000 & 1658,000 & 1538,840 & $\geq 800$ \\
\hline Flow (mm) & 3,760 & 3,760 & 3,840 & 3,920 & 4,000 & 4,080 & $2-4$ \\
\hline $\begin{array}{l}\text { Marshall Quotient } \\
(\mathrm{Kg} / \mathrm{mm})\end{array}$ & 340,270 & 367,700 & 379,660 & 402,040 & 416,130 & 378,360 & $\geq 250$ \\
\hline VIM Marshall (\%) & 4,682 & 4,594 & 4,437 & 4,337 & 4,281 & 4,231 & $3-5$ \\
\hline VMA $(\%)$ & 15,150 & 15,344 & 15,280 & 15,226 & 15,197 & 15,166 & $\geq 15$ \\
\hline VFB $(\%)$ & 69,098 & 70,060 & 70,961 & 71,518 & 71,831 & 72,109 & $\geq 65$ \\
\hline
\end{tabular}
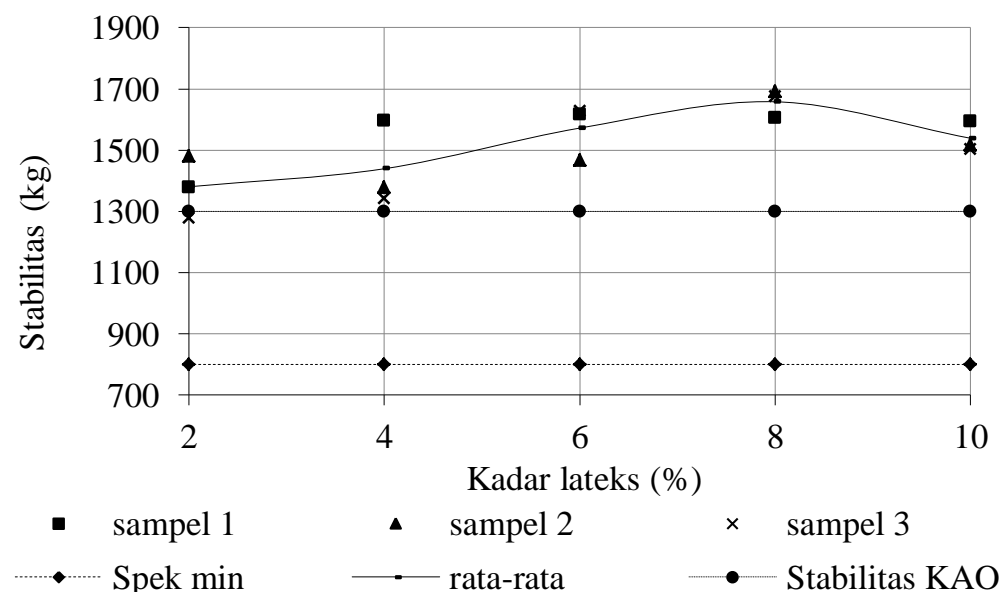

Gambar 2. Stabilitas vs. kadar lateks

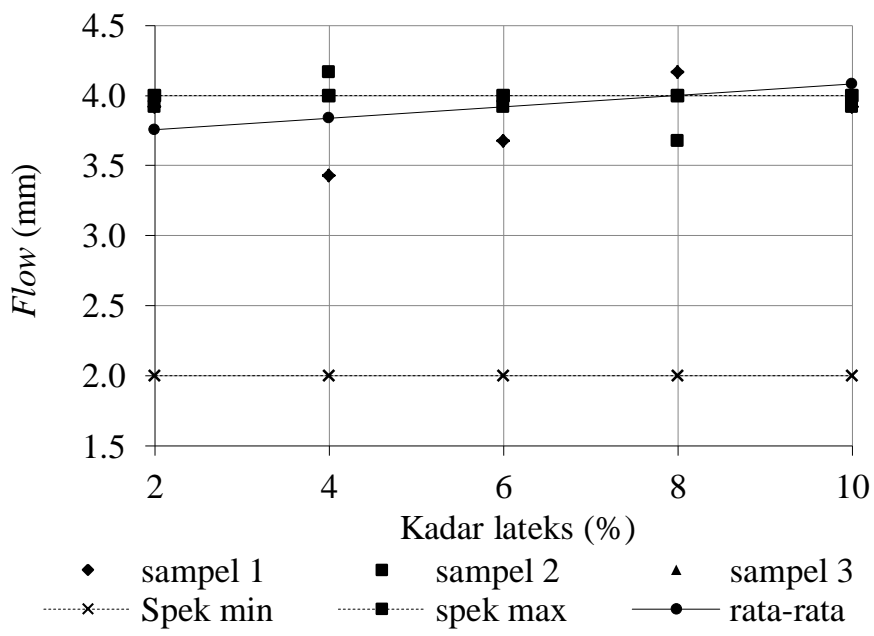

Gambar 3. Flow vs. kadar lateks 


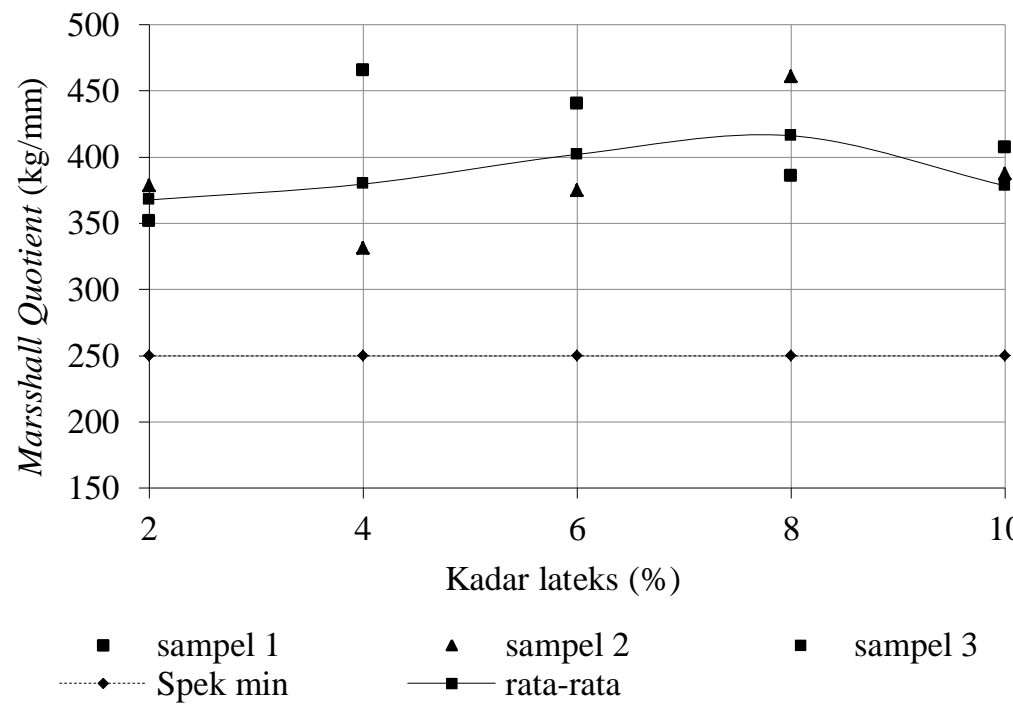

Gambar 4. Marshall Quotient vs. kadar lateks

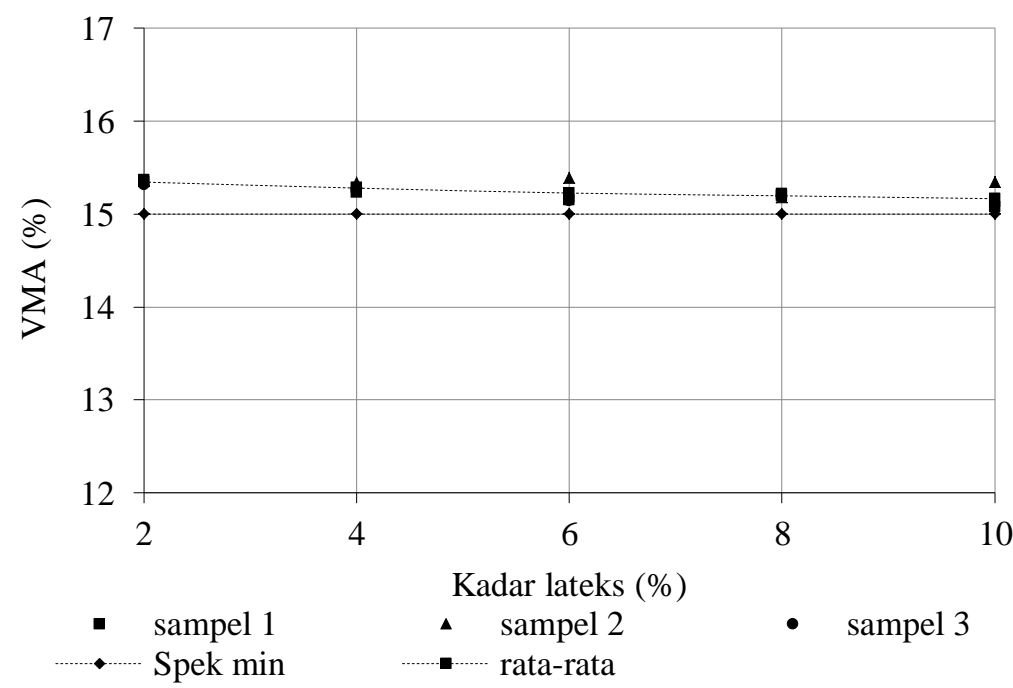

Gambar 5. VMA vs. kadar lateks

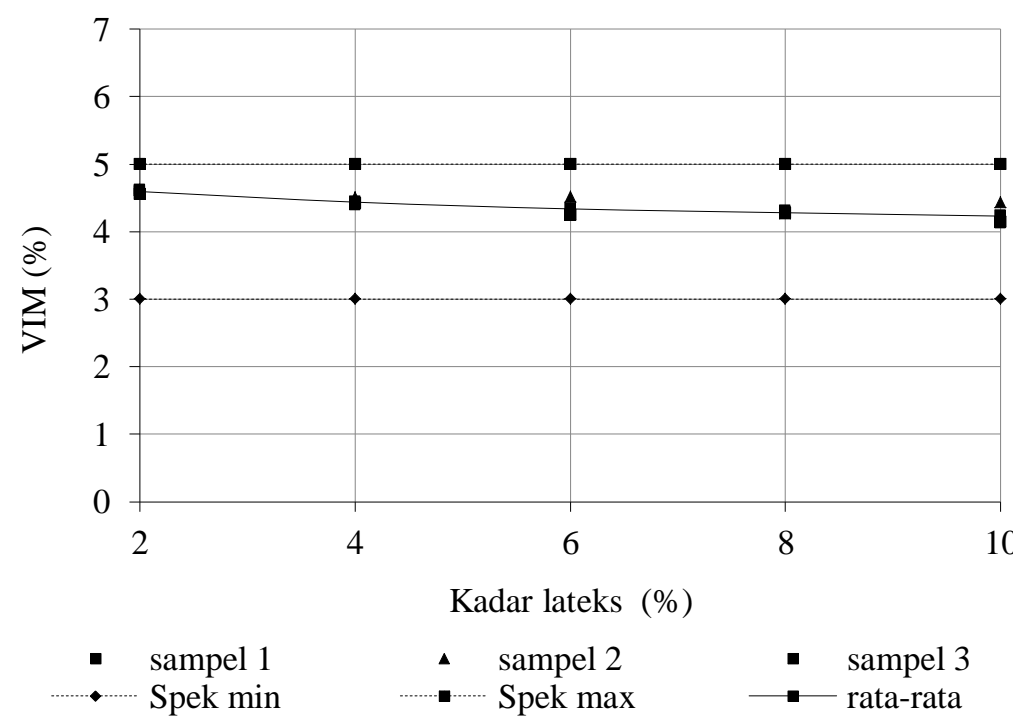

Gambar 6. VIM vs. kadar lateks 


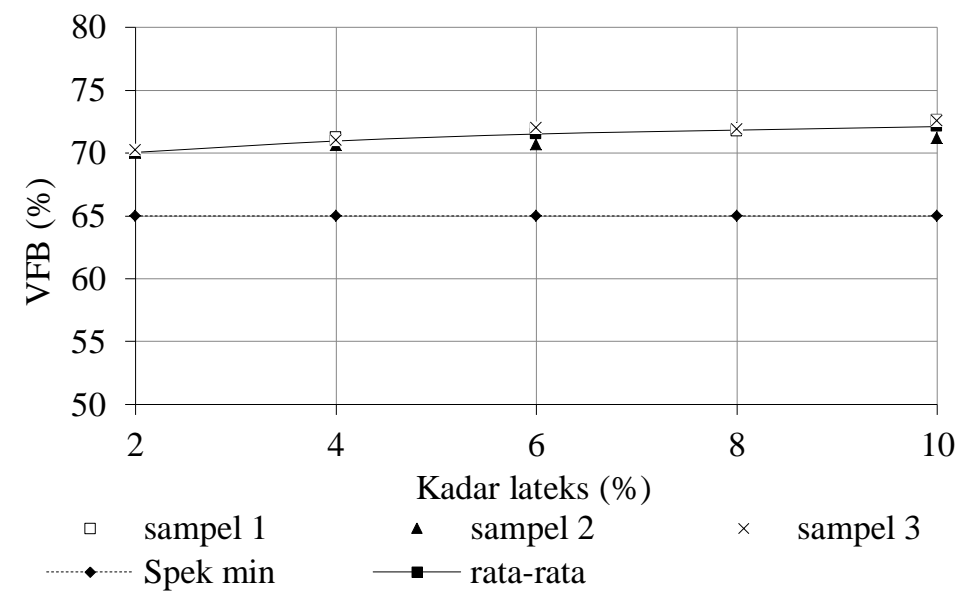

Gambar 7. VFB vs. kadar lateks

Tabel 11. Pemeriksaan aspal penetrasi $60 / 70$ dengan ditambah lateks

\begin{tabular}{lccccc}
\hline \multicolumn{1}{c}{ Pengujian } & Aspal 60/70 & $\begin{array}{c}\text { Aspal 60/70 + } \\
\text { lateks 4\% }\end{array}$ & $\begin{array}{c}\text { Aspal 60/70 + } \\
\text { lateks 6\% }\end{array}$ & $\begin{array}{c}\text { Aspal 60/70 + } \\
\text { lateks 8\% }\end{array}$ & Spesifikasi \\
\hline Penetrasi & 66,71 & 61,6 & 59,26 & 57,07 & $60-70$ \\
Titik Lembek & $49,75^{\circ} \mathrm{C}$ & $52,5^{\circ} \mathrm{C}$ & $53,75^{\circ} \mathrm{C}$ & $55^{\circ} \mathrm{C}$ & $\geq 48$ \\
Daktilitas & 136 & 102 & 82,25 & 63,65 & $\geq 100 \mathrm{~cm}$ \\
Titik nyala & $347^{\circ} \mathrm{C}$ & $341,5^{\circ} \mathrm{C}$ & $338,25^{\circ} \mathrm{C}$ & $335,5^{\circ} \mathrm{C}$ & $\geq 232^{\circ} \mathrm{C}$ \\
\hline
\end{tabular}

Pemeriksaan aspal (pada KAO) dengan penambahan lateks

Aspal pada kadar aspal optimum ditambah lateks dengan variasi 4\%, 6\%, 8\% (terhadap total perekat). Adapun pemeriksaan yang dilakukan adalah pengujian penetrasi, titik nyala, titik lembek, dan daktilitas. Hasil pengujian dapat dilihat pada Tabel 11. Dapat dilihat bahwa nilai penetrasi dan daktilitas yang sensitif terhadap penambahan kadar lateks. Sampai dengan penambahan aspal dengan lateks 4\%, masih memenuhi spesifikasi. Karena itu uji ketahanan deformasi dinamis (dynamic creep) dilakukan pada kadar lateks $4 \%$.

\section{Hasil uji dynamic creep}

Hasil uji ini disajikan pada Gambar 8 dan 9 pada kadar aspal optimum dengan kadar lateks $4 \%$.
Gambar 8 memperlihatkan penambahan lateks $4 \%$ meningkatkan ketahanan terhadap deformasi sebesar $11,9 \%$, demikian juga kekakuannya yang dihitung dengan Persamaan 2, meningkat 14,2\% (Gambar 9).

Kemiringan bagian lurus/linier dari Gambar 8 yaitu dari load cycles 2200 keatas, disajikan pada Gambar 10, dimana persamaan garis liniernya (Persamaan 3), memberikan koefisien variable $\mathrm{x}$ (nilai a atau kemiringan) senilai 0,215 untuk campuran AC-WC tanpa lateks, dan dengan nilai $\mathrm{a}=0.065$. Sesuai Tabel 2, pada temperatur $40{ }^{\circ} \mathrm{C}$ (> $30{ }^{\circ} \mathrm{C}$ ) kedua campuran memiliki kemiringan $<0,5$, yang sesuai untuk jalan dengan lalu lintas berat (> $10^{6}$ ESA). Campuran dengan tambahan lateks lebih mampu menahan beban karena nilai kemiringannya lebih kecil.

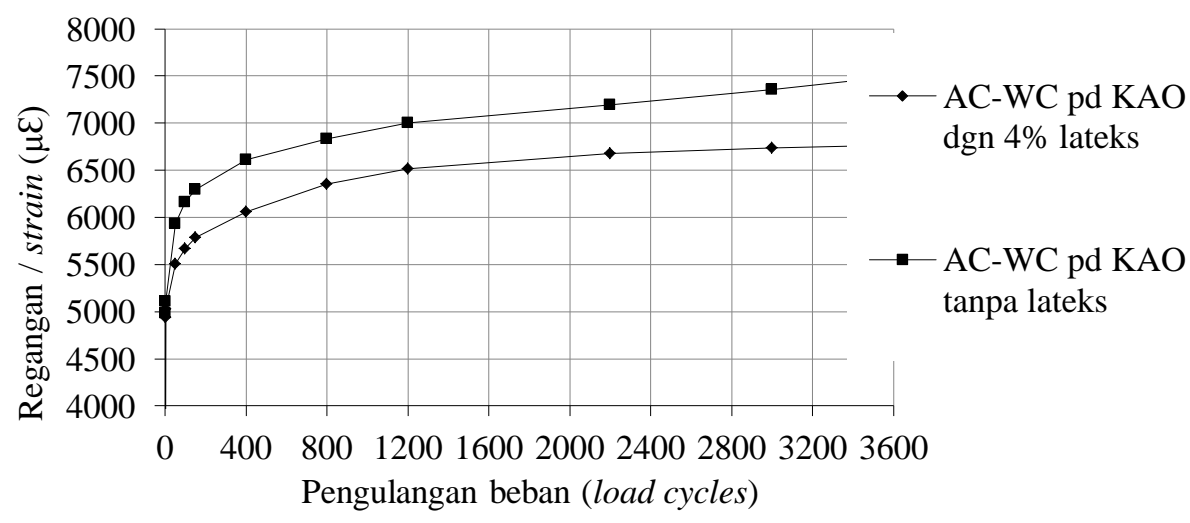

Gambar 8. Pengulangan beban vs regangan 


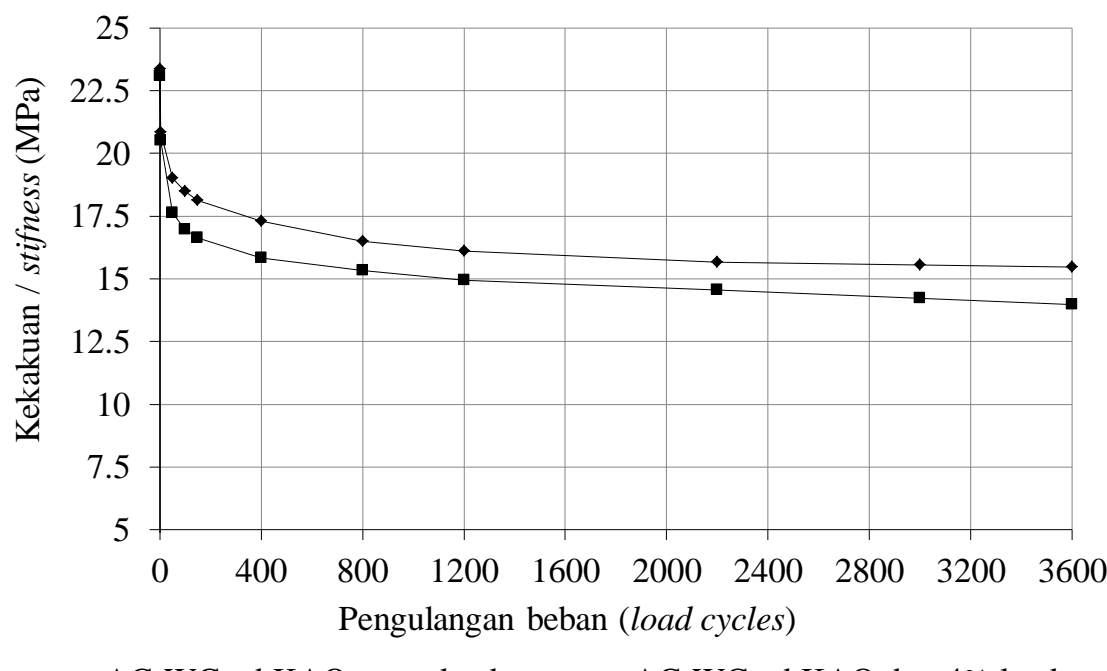

- AC-WC pd KAO tanpa lateks - AC-WC pd KAO dgn 4\% lateks

Gambar 9. Pengulangan beban vs kekakuan

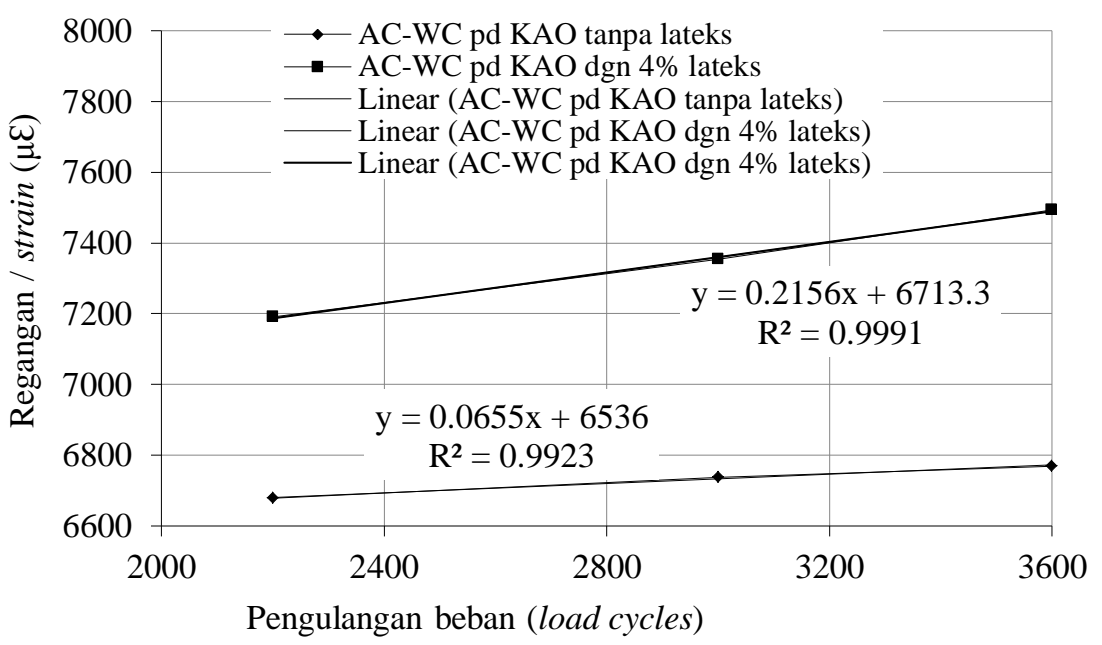

Gambar 10. Pengulangan beban vs regangan pada bagian linier

\section{Kesimpulan}

Sesuai hasil analisis, diperoleh kesimpulan:

1. Penambahan lateks ke dalam campuran ACWC menunjukkan nilai stabilitas Marshall yang semakin baik, nilai flow semakin tinggi, Marshall Quotient semakin baik, nilai VIM yang semakin rendah, nilai VMA yang semakin rendah serta nilai VFB yang semakin tinggi. Dari hasil pengujian menunjukan bahwa nilai stabilitas tertinggi diperoleh pada campuran dengan kadar lateks sampai $8 \%$ terhadap total perekat, adapun nilai stabilitas yang diperoleh sebesar $1658,00 \mathrm{~kg}$.

2. Dipilih variasi lateks $4 \%$ terhadap total perekat, karena dari hasil pengujian aspal memenuhi spesifikasi.

3. Pada penambahan $4 \%$ lateks ketahanan campuran terhadap deformasi meningkat sebesar $11,9 \%$, dan kekakuannya meningkat 14,2\%. Campuran dengan dan tanpa lateks memiliki nilai kemiringan tes creep dinamik (dynamic creep slope), sesuai untuk lalu lintas berat.

\section{Daftar Pustaka}

Alderson, A., 1995. Gyropac and Matta Training Cours, Australian Road Research Board Ltd.

Amiruddin, 2012. Kajian Eksperimental Campuran HRS-WC dengan Aspal Minyak dan Penambahan Aditif Lateks Sebagai Bahan Pengikat, Jurnal Teknik Sipil, Universitas Trisakti Jakarta.

Aryadi, B, 2012. Komposisi pada Tanaman Karet. http://bilyaryadi.com/komposisi-lateks-padatanaman-karet.html aryadi 2012. diakses tanggal $11 / 01 / 2015$. 
Badan Standarisasi Nasional (BSN), 2008a. Cara Uji Berat Jenis dan Penyerapan Air Agregat Halus, SNI 1970:2008.

Badan Standarisasi Nasional (BSN), 2008b. Cara Uji Berat Jenis dan Penyerapan Air Agregat Kasar, SNI 1969:2008.

Badan Standarisasi Nasional (BSN), 2011. Cara Uji Berat Jenis Aspal Padat, SNI 2441:2011.

British Standard (BS), 2005. Bituminous mixtures - Test methods for hot mix asphalt, Part 25: Cyclic compression test, BS EN 12697-25:2005.

Departemen Pekerjaan Umum (DPU), 2010. Spesifikasi Campuran Beraspal Panas 2010 Revisi 3.

Dewan Standardisasi Nasional Indonesia (DSNI), 2002. Bahan Olahan kare, SNI 06-2047-2002.

Departemen Pekerjaan Umum (DPU), 2003. Metode Pengujian Campuran Beraspal Panas Dengan Alat Marshall, RSNI M-01-2003.
Pradnya P., G., 2015. Analisis Karakteristik Campuran AC-WC (Asphalt Concrete Wearing Course) Dengan Menggunakan Bongkaran Aspal Beton Lama Sebagai Bahan Dasar Dan AAC (Autoclaved Aerated Concrete) Sebagai Filler, Tugas Akhir yang tidak dipublikasikan, Jurusan Teknik Sipil Fakultas Teknik Universitas Udayana, Denpasar.

Purbaya, 2011. Pengaruh Beberapa Jenis Bahan Penggumpal Lateks Dan Hubungannya Dengan Susut Bobot, Kadar Karet Kering Dan Plastisitas, Prosiding Seminar Nasional AVoER ke-3 Terpublikasi, Jurusan Teknik Kimia Fakultas Teknik Universitas Sriwijaya Palembang, Palembang.

Ridha, R., SP. (2011). Jenis - Jenis Karet Dan Manfaatnya.

hhp://riskyridhaagriculture.blogspot.co.id/2011/12/ normal-0-false-false-false-in-X-none-x.html? $\mathrm{m}=1$.

Diakses tanggal 11/01/2015

Sukirman, S., 2003. Beton Aspal Campuran Panas, Penerbit Granit, Jakarta. 